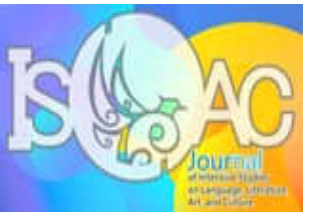

ISLLAC : Journal of Intensive Studies on Language, Literature, Art, and Culture

Volume 2 Issue. 1, 2018

Journal homepage : http://journal2.um.ac.id/index.php/jisllac

\title{
AUDIOVISUAL METHOD IN CHILD LITERARY APPRECIATION LEARNING FOR CHARACTER BUILDING BASED ON LOCAL WISDOM OF KEMBARAN TRIBE IN WEST PAPUA
}

\author{
Adolina Velomena Lefaan* \\ Indonesian Education Faculty of Teachers' Training and Education University of Cenderawasih
}

\begin{tabular}{l} 
A R T I C L E I N F O \\
\hline Keyword: \\
Literature learning, \\
Child Literature Appreciation, \\
Character, \\
Audiovisual Method, \\
Ecology, and \\
Local Wisdom of Kembaran \\
Tribe in West Papua
\end{tabular}

\begin{abstract}
A B S T R A C T
The reality of modern development in education which is wide opened, does not only have positive effects but also negative effects to the mindset of schoolchildren, and in turns, it changes their characteristics too. The cultural environment in the family has also started to be influenced by many kinds of development through the social media. It is an indication that the modern life has made the parents worried about their children's characters. The phenomenon can be seen from the news headlines about the life of the learners from preschoolers until the college students. This writing is aimed at implementing audiovisual method in the learning of child literature by utilizing folktales (child stories) based on the local wisdom of Kembaran tribe in West Papua, as a medium for character building in order to develop the awareness to love the environment and to have a sense of belonging to the environment as a form of a real life. By using ethnographic approach, it was found that the child literature of Kembaran tribe can build the character of the children, can establish the sociocultural values along with the awareness to keep up the spirit and to preserve the local wisdom in West Papua.
\end{abstract}

\section{INTRODUCTION}

Literature is a human experience. It humanize our life, and it plays an important role in our life. Therefore, literature is humane in nature. Literature in the process of learning, may train the language skills, increase the knowledge on the life skills, build the personal experience, give satisfaction, and may build human characters (Chandra \& Suyitno, 2017). The learning of literature includes all aspects of literature such as literary theory, history of the literature, literary criticism, comparative literature, and literature appreciation. From those five aspects, the literary appreciation is considered as a mentor for the difficult aspect of literary learning. The reason behind this is that literary appreciation learning focuses more on the dominant affective aspects such as attitude, sense, heart, values, moral, culture, emotion, and behavior. Teachers in West Papua often complains that literary learning is complex and is difficult to be practiced, especially for child literature. It is difficult indeed to practice it at school because the evaluation is related to the attitude and values. Should we ignore the complaints? No, of course not. We should take a role as motivators and help the teachers to give solution to their problems. In regard with this fact, especially in West Papua, a proper analysis should be conducted. For instance, the teachers may have not had any experience nor information about child literature appreciation learning. The teachers may also had not had involved in any training related to child literature appreciation professionally. The teachers may play roles as the teachers in remote area (remote, isolated, and underdeveloped areas), and therefore, they are hard to accept new information about literary knowledge. We cannot judge the weaknesses of the teachers too soon, but we should consider many things in regard with their service. In regard with this, we should prioritize the need of (child) literature appreciation learning, that is by giving the understanding

\footnotetext{
" Corresponding author.

E-mail addresses: inasamosir@gmail.com (Adolina Velomena Lefaan)
}

ISSN : 2597-7385 (Online) - ISLLAC : Journal of Intensive Studies on Language, Literature, Art, and Culture is licensed under Creative Commons Attribution-ShareAlike 4.0 International License (http://creativecommons.org/licenses/BY/4.0/).

28 ISLLAC : Journal of Intensive Studies on Language, Literature, Art, and Culture 
about the concept of Appreciation. It can be done by making facilitation and training on the literary substance (literature appreciation). According to Effendi (in Esti Ismawati, 2013:1) is an activity of familiarizing, getting involved, understanding, and enjoying literary works in order to develop knowledge, understanding, sensibility, comprehension, enjoyment, and appreciation to those literary works. If the concept had been well understood, then we move to the child literary appreciation learning.

The teaching of literature has got to do with human life which includes cultural values, humanity, social values that we can find in poems, proses, and plays. In regard to life, literary appreciation learning makes use of media such as poems, folktales, and audiovisual to be used to express the value of life according to the themes in literary works. Therefore, it can be said that literacy learning is a medium for students to get values from the literary works in which they learn it in an enjoyable atmosphere under the guidance of a teacher or a lecturer. In this way, values, sense, and attitude of appreciation to the growth and building of characters building of the learners can be developed.

Child literature is the literature which aims at the children and with the unique language of children. If the writer of child literary works is an adult, then the writers should understand about the suitable them and should adapt to the children's thinking ability, and the language is ideal and is suitable with children's characteristics. In fact, children have a wild imagination, and they are very fast incomprehension, are very sensitive to the beauty of the natural environment, eagers to know, and they always want to try something new. In addition, they are more ignorant than the adults. Children are excited to have a lot of activities, and they imitate what they see. This phenomenon implies that child literature is suitable for children. In regard with child literature, Sarumpaet stated that the passages for children are really aimed at being read by children under the guidance of the adults, and the writer is also adults (1976:24). Besides that, Sugihastuti confirms that child stores are written by adults. In the process of writing, the writer imagines the past lives of his/her, the childhood. Child stories are written for the children, (1996:69). From the two statements, it can be inferred that child literature writer is an adult who has a skill in writing child literary works with child point of view. Sugihastuti asserted that the writer of child literary works should consider the intellectual levels and imaginative power of children as the readers. Therefore, the child stories cannot be kept away from their rationals and the imagination. The writer of child literary works should understand the world of children in order that their works can be accepted by children (1996:69).

The learning of child literature cannot be separated from the curriculum. It highlights that the basic competence for child literature learning in the elementary school level consists of listening, speaking, reading, and writing. In listening aspect in literature, the learners can appreciate and express the literature by listening to the literary works. In speaking aspect, the learners appreciate and express the literature by reading aloud the literary works. Reading aspect; in this aspect, learners are expected to be able to appreciate and express literary works by reading them. And for writing aspect, it is expected that the learners be able to write poems or simple stories of their own. The learning of literature as a competence does not need to be confirmed as a specific subject in curriculum 2013, but the teacher of Indonesian subject can internalize it when they teach Indonesian subject. The textbooks of elementary school should consider and use the language for the comprehension level of the students. The language of the poems should not only beautiful but the message to also be clear for them.

Nurgiyantoro (2005:49) who adopted the ideas from Bradly (1991) and Huck,et al (1987) asserted that the selection of literary passages for children should consider the child development; intellectual, moral, emotional, linguistic development stages, and the development of stories concept because every stage has a different characteristic in line with the development of the children. The selection of the reading passages should be based on the materials which are easily understood by the children and should be written by considering simplicity or complexity of the vocabulary and structure. However, it serves to improve the language skill and arts of the children. To appreciate the passage of the learners, teachers should consider the intellectual aspect, emotional aspect, child language arts, and the organization structure of passage content.

Implementation of the appreciation of literary learning is varied. It depends on the learners' application of the learning process in the classroom. In regard with this phenomenon, this writing is aimed at giving solution about the strategy and technique to be used in implementing creative learning process, that is by using an audiovisual method based on the local wisdom of Kembaran tribe in the West Papua. We use folktales which are related to the children world. By using this strategy, it is expected that the learning process in the classroom can make use of local stories to find the significance. This concept is in line with excit8ing and meaningful learning concept in Contextual Teaching \& Learning (CTL). The objective of CTL is to help students find meaning in their learning by making a correlation between the academic subject and their daily life. They make significant relationship which results in meanings by doing a self-regulated 
learning, cooperating, making use of critical and creative thinking, appreciating other people, reaching a high standard, and playing roles in authentic assessment tasks, (Elaene, B. Jhinson, 2014: 88). This concept implies that the learning around the lives of children will be more concrete that in turn will facilitate the students in comprehending the subject as well as giving meaning to their learning process. The selection of audiovisual method with folktales as the content is a representation of literary ecology for social practice in supporting the learning process of literary appreciation for children. The content of Kembaran folktales represents the daily life which is close to the daily life of the children. In addition, the content of the stories of Kembaran folktales teaches values and teachings about keeping the brotherhood, keeping the harmony among the tribes, and the harmony with God, as well as the ecological harmony.

The implementation of this method has been covered in the context of digital literacy ecology learning based on local wisdom in West Papua. Concretely, the audiovisual method is a simulation and a motivation to learn for children of 6-9 years old in West Papua. In this way, children will enjoy the learning process which is active, innovative, environmentally creative, and exciting (PAILKEM) in communicating with teachers and their peers. This study is natural in setting and using ethnographic approach. The tendency to use this approach is based on the materials are from the culture of a certain tribe, in this case, folks for children. As had been stated by Malinowski\& Radcliffe-Brown (in Spradley, 2007: xi), the objective of ethnography is to describe and develop social structure and culture of a society. Today, culture is defined as "the way of life of a society". James P. Spradley asserted that culture is a system of knowledge acquired by a human through a learning process to be used to interpret the world around them, and also to develop strategies to face the world, (2007xiv). The content is related to the culture implementation, literature, and the ecological wisdom of the society which was created through the stories such stated by the three experts above. By using this learning approach, it is expected that it will help the teachers, learners, and the local society to be open to the modern education, but in the same time still preserve the cultural heritage through folktales or myths.

The audiovisual method is a method which uses media such video, tape recorder or television program so that the teaching and learning process will be more lively and exciting, (Iskandar and Sunandar, 2011:44). It is a creative method, and it will give positive impact to the teachers and students in creating an exciting and challenging learning environment, that in turn the children will be able to communicate, and it will also motivate the children's emotion to find new and useful things in their life.

In regard with the concept of character building, Nurhayati (in Wibowo, 2013:19) said that the learning of literature is closely related to the character building because the learning of literature, and literature in general, discuss life and its values in which they are directly related to the human character building. This proposition is in line with audiovisual method concept using Kembaran folktales in literary appreciation learning in order to develop awareness of possessing an environment as a medium for character building based on the local wisdom in West Papua.

\section{THE ROLE OF LITERATURE IN BUILDING CHARACTER BASED ON ECOLOGICAL LOCAL WISDOM OF KEMBARAN TRIBE IN WEST PAPUA}

Using the concept that literature humanize the life of people, literature in learning has a very important role in the character building of the children. The character of a child is developed when he/she makes interaction, both in the family and in the school environment. Literature is not only an agent of change to develop the humane aspect, but it also harnesses the moral and ethics to the individuals in order to create a civilized society (Firmansyah in Wobowo.2013:20). Similarly, Fredrich Schiller also stated in Esti (2013:20) that literature can be used as a kind of game to balance the mental abilities of a human, as a compensation for the excessive energy. By using literature a person's creativity, emotion, sensitivity, as well as the sensitivity towards humanity are developed, and in turns, it will prevent the person from doing any destructive and narrow-minded actions (Wibowo, 2013). In fact, the imaginative elements of literature may guide children to have a broad insight into thinking, taking actions, and even creating creative works. Imagination is a power or a process to produce mental images and ideas. In psychology, imagination is a process to rebuild a perception toward an object which had been given a comprehensive perception before. Actually, imaginative things had been put into our curriculum, especially in regard to the literary appreciation learning concept. Why? Because we need it in literary appreciation. In principle, we use imaginative way of thinking when we appreciate literary works. For example, in poetry appreciation or in the process of a folktale into a play, imagination is used to express the actions of the characters in it. Actually, this model had been integrated implicitly with the curriculum substance, and it is the task of the language teachers to accommodate it in the teaching and learning process.

Curriculum always changes, and in the education politics, it is positive. The reason is that we live along with other countries who also cooperate in education. We should be able to compete and to 
contribute to education. Curriculum greatly influences the teachers in the teaching and learning process, the Learning process is not merely a process of transferring knowledge from the teachers to the learners, but it has also taught the students to appreciate themselves, other people, and appreciate the differences. Ki Hajar Dewantara (1977) make an analogy about education without culture. He said that it is like a ship on the sea without any compass. Not only that, Ki Hajar Dewantara had also given an example of how to design a learning curriculum with a proper cultural strategy. The curriculum which is not designed based on our culture will lose the spirit and left an empty space in the heart of our children. We cannot agree more with the statement of Ki Hajar who said that education without culture is like a ship without a compass, (adapted from Wibowo 2013:13). Furthermore, Wibowo (2013) asserted a curriculum concept which was supported by the first president of Indonesia, Soekarno, that we do not need to seek for the foundation of the curriculum because our nation has richful knowledge and wisdom. Soekarno said that he had never created Pancasila (the Five Basic Principles), instead, he assembled it from the wisdom and knowledge from the elders, and then made it as a systemical philosophy of life named Pancasila. In regard to this, Licona give gave a concrete example about a teacher named "Bill Elasky with the six graders to show the role of the curriculum as a Moral education". Bill Elasky is a part of an emerging trend; teaching the values of life to the environment as well as skills and academic knowledge as the main agenda of the school. Awareness about the teaching of values in academic curriculum is like a sleeping giant. Another significant method in teaching values is that the teachers become the role model and the guide to develop civilized society and create an atmosphere of respect each other and sense of responsibility in the classroom. The academic curriculum is the most important one at school. We should not miss the opportunity to use curriculum as a media to develop moral values and ethical awareness (2015: 244).

Our founding father Soekarno had given an example that the cultural strategy should be originated from ourselves, and is not an imitation from other nations. It means that we can take the moral values developed by our ancestors. Kembaran people in West Papua also has a local culture that teaches positive values to the young people. Like the philosophy of Kembaran tribe, "Land is the Womb of Mama". (Adolina Samosir Lehman, 2010: 108). The land is the representation of the body of a Mama (a woman). The woman is unique and full of mystery. A woman has a womb as a place for pregnancy and to bear a baby. There is a folktale in Kembaran tribe which tells about their life on the ground that is like a womb for a woman. It means that they used to live under the ground, and then went out and continue the generation and passed away above the ground. The story was expressed in the oral literature of Kembaran tribe such as retold by the people of Kembaran, and then it was made as an audiovisual by the topic of "Identity of Kembaran People in the Myths of West Papua". The audiovisual was then become the topic of this writing.

The content of the oral literature was for elementary school students as a material for literary appreciation learning based on character building with local wisdom ecology. Curriculum Center of National Education Ministry (2011:10) has formulated 18 subjects of character building which includes the following aspects: religious, honest, tolerant, discipline, hard work, democracy, eagerness, nationalism, love of the country, appreciating the achievement, friendly/communicative, peaceful, social care, love to read, environmental care, and responsibility. Character building is aimed at improving the administration and achievement of education at schools with the objectives of building character and good attitude of the learners in an intact, integrated and balanced way in accordance with the graduation competence standard. By applying character building, it is expected that the learners can independently improve and use their knowledge, analyze and internalize, and personalize the good characters and attitudes, that in turn it will be represented in the daily behavior. The concept had been stated in Permendikbud. (Ministry of Education and Culture Regulation) number 23 the year 2015 about character development to support literacy movement. The point is that character building cannot be separated from the role of the teachers because everything that the teachers do will influence the character of the learners. The character is built from three correlated parts, moral knowledge, moral feeling, and moral behavior (Lickona, 1992:72).

The values of character building in the literary appreciation learning for child literature using audiovisual method is expected to be internalized wisely from the storytelling. Those values asserted the significance for the learners from preschoolers until high school students, or even college students, and as a knowledge for the public in general. A character cannot be inherited, cannot be bought, cannot be exchanged. The character should be built and developed consciously, and through a process which is not instant. The entrenched character will produce great individuals.

The character should be based on our own culture, by exploring the great values in the local wisdom. The exploration of local wisdom values based on the character building is in line with the recommendation of UNESCO year 2009 which asserted that the exploration of local wisdom as the foundation of character building, and education in general, will bring about the attitude of respecting each other among the different ethnics, tribes, nations, and religions so that the diversity will be preserved. In 
line with this concept, Keraf in Wibowo (20013) stated that local wisdom is any kinds of knowledge, belief, comprehension, or insight and customs or ethics which guide the human behavior in the life of the ecological community. Afterward, Fransic Wahono (2005) has fully defined local wisdom as skills and strategies.to manage the environment in order to harmonize the ecological balance which had been tested for centuries by disasters and troubles, and also by human errors. Local wisdom is not only a matter of ethics. Instead, it also includes norms, actions, and behavior. Therefore, local wisdom may serve likes a religion to guide human in behaving in the context of daily life, and in determining the future of human civilization.

The implementation of the ecological concept in this context is focused on the natural environment as retold in the stories in the audiovisual of Kembaran tribe. Literary ecology studies had been known and consolidated as a literary ecological criticism in the early 1990s, but the term has appeared since 60s and 70s coined by William Rueckert to refer to the implementation of the ecological concept in literature, (Glotfelty, 1996:20). In early 20th century, there are many activities done by the natives who complained about injustice and was expected the law enforcement in regard with the loss of territory of their ancestors, the dismissal of their hunting areas, fishery/fish catch areas, cattle farms, and the dismissal of their languages without prior consultation, Northern British Colombia, Thompson, monologue ritual to praise the river (Huggan and Helen Tiffin, 2010:123 in Juanda HISKI article 2016). Ecocriticism was introduced to the traditional schools in regard to natural literature, like the pastoral study in Ameria by Jefferson and Bartram to Thoren and Muir. William Rueckert introduced ecocriticism in his article in Iowa review under the title Literature and Ecology, and Experiment in Ecocriticism. year 1992 literary studies with environment and ideas and interdisciplinary information, literature with an environment which considers the relationship between human and the surrounding, (Glotvelty 1996: xvii). Literary ecocriticism is manifested in many fields such environmental awareness is a text study and a study which relates the text and physical environment, and cultural environment. Ecocriticism identifies and gives orientation to the environmental workers in three things such as had been stated (Buel, 2001), ; (1) who works in the world with human history and natural history backgrounds; (2) complicated job; works for ethical orientation, considering environmental aspects. American tradition in Bioregional, the19th century writings by authors such as Susan Fenimore Cooper and Celia Thaxter, which emphasized in bioregions, plants, animals, weather, and cultural practice in the form of maintenance in the context of local biology (Lynch, et al. 2012:12). This concept is similar to the ecological wisdom in the folktales of Kembaran tribe in West Papua. It means that the context of environmental study as a form of life in the human activities with human as a subject can also be found in Weriagar district in the life of Kembaran tribe in West Papua. It can be inferred that the relationship between education, culture, and environmental crisis the practice of survival of a culture and belief in the environmental preservation from generation to generation. A great nation is a nation that can appreciate the romance of its natural environment wisely. The child literary appreciation that is presented in this writing is "Nintendo and Matirete" in the life Kembaran tribe as a representation of ecological, cultural, and literary life in West Papua.

\section{AUDIOVISUAL METHOD IN THE CHILD LITERARY APPRECIATION BASED ON THE LOCAL WISDOM OF KEMBARAN TRIBE}

The word method was originated from a Greek word "methods" meaning a way or a path. Thus, a method is a way to be used to reach a determined objective. Based on the lesson plan, each component is dependent on the objective. The lesson plan method is also determined by the objective. In learning and teaching, a method is required for education and the use is varied, depends on the final objective of the teaching. In line with this, Murtadlo (201146 in Zainal 2016) asserted that learning method is a procedure, an order, steps and ways to be used by the teacher to implement the lesson plan in a real action to reach the objective of the learning. Thus, a method is a learning procedure focused on the fulfillment of the objective.

In regard to this concept, this writing uses the audiovisual method. Such as argued by Muthoharoh (2010) audiovisual method is a way to present the learning materials by using the materials in order that the learners can watch, observe, and experience them directly. The point in the teaching using audiovisual method is the use of teaching media such as film strip, radio, map images, et cetera. Some benefits of audiovisual teaching aids which are used by learners when implementing this method are; (1) assisting them to give the first concept or the correct impression; (2) giving better understanding; (3) complementing other sources of learning; (4) adding teaching method variation; (5) improving their intellectual curiosity; (6) saving the time; (7) stimulating the interest; (8) keeping longer retention about the learning; (9) reducing unnecessary repition; and (10) giving a new concept from something outside the common experience. This method is aimed at giving real experience to the learners. 
The chocie of this method is aimed at; (1) assiting and motiviating the Indonesian languaga and literature teachers in the process of teaching and learning at school; (2) motivating the teachers to create their own teaching media by using the existing teaching resources which sorrounds the life of the children, especially the ones related to the child culture ; (3) develop the care of the teachers to the local wisdom that can be used as a method and as critical and creative learning materials; (4) enrousng the interest of the children to learn by using local storeis in order to preserve the local culture; (5) developing the awareness, love, care, and sensitivity to the environment as the learning resources and the medium of cultural life; and (6) developing and building character based on local wisdom of West Papua. The audiovisual method that presents the folktales of Kembaran people is a message to comprehend and preserve the local culture of Kembaran tribe in West Papua Barat as a part of the national cultural heritage to be learned by the young in all over the country. By using this method children will get the knowledge in literary appreciation learning, children will acquire cultural knowledge, sense of belonging to the environment as a medium to build the character based on the local culture of West Papua. In this way, the language and literature learning at school will be able to produce skillful students in term of speaking, verbal and oral arts, and in writing.

\section{USING AUDIOVISUAL IN LEARNING}

Using audiovisual as a teaching medium is not a new thing. Audiovisual can arouse the interest unconsciously, such as feeling or emotion when watching a live performance. The feelings and emotions can be sad, mourned, happy, proud, laughter, relaxation, love, fantasy, and even bored. The emotions are often stimulated or improved by the feeling shaped by specific visual scene, player or speaker or music ensemble. An audiovisual show can give a strong effect to the mind and emotion of a person who watches it. It is very impressive so that a person may be motivated after downloading the performance. The audiovisual show of Kembaran folktales as a child oral literature in an audiovisual version is used to stimulate the thinking ability and in taking action (in the affective domain) to the children in the learning process, as well as to arouse the curiosity of children to the meaning of the stories. The results of the learning process which are found in this method implementation are (1) attracting the children and adults who have wacthed the performance; (2) focusing on the concentration of the children to the content of the story; (3) arousing child interest; creating anticipative sense; (4) giving relaxed feeling to the children in the process of giving assignment in learning; (5) stimulating the children or the imagination of children and teachers; (6) improving the attitude of the children in regard with the content of learning; (7) improving the memory retention of students; (8) improving the child comprehension; (9) harnessing children creativity; (10) arousing the ideas from children; (11) providing an appropriate atmosphere; (12) creating impressive visual image; (13) inspiring and motivating the students and the teachers; (14) making the learning process enjoyful; (15) reduding the worriness to frightening topics; (16) bringing students and teachers in a deep learning and teaching process.

The benefits of the show can also influence the right and left brains, especially related to two ways of thinking, verbal and nonverbal, such as had been initiated (Gazzaniga, 1991 and Sperry, 1973), the left brain is dominated by logical side and analysis which processes information orderly such as in mathematics, logic, and language. This is also a verbal side which is structured factually, controlled, rational, organized, planned and objective (Miller,1997). On the other hand, the right brain is the nonverbal side, creative and spontaneous, emotional, unorganized, experimental, emphatic, subjective, intuitive, and seeking relationship. The right brain is focused on arts, color, picture, and music (Jourdan, 1997: Polk \& Kertesz, 1993). A video clip involving the two spheres of the brain, the left sphere processes dialog, plot, rhythm, and lyric; the bright brain processes visual image, relationship, sound effect, melody, and harmonious relationship (Herbert \& Peretz 1997, Schlaug, Janke, Haung, Staiger, \& Stainmetz, 1995).

In addition, there are some learning theories that had tested the coding of verbal communication, including visual code, auditory, articulation, and nonverbal communication, which may try to find shapes, sound, kinesthetic action, and emotion. Those theories had been related to the multimedia and research had tested the application in the classroom. Cognitive learning theory of Mayer $(2001 ; 54)$ is related to five steps (1) selecting relevant words to be process in the memory of verbal work, (2) selecting relevant images to be processed in the memory of visual work, (3) arranging words to be selected as mental model verbal (4) arranging selected images as the visual mental models, and (5) integrating verbal and visual representation and the prior knowledge. The results of Mayer's research indicates that the adjacent verbal and visual material presentation such as in video with dialog and narration which is integrated most effectively for beginners and visual students. An audiovisual method in this writing has a very important meaning and beneficial for the children in a process of literary appreciation learning, especially in preserving the local wisdom culture through this method. 


\section{CONCLUSIONS}

Literary appreciation learning for children is a learning practice based on the real life of a human, and ecology is a form of care which has local wisdom culture. Ethical people as the owners of the cultural environment in the practice of social life are people who have a sense of humanity. Thanks to God who gives the life to be used and preserved wisely.

The substance of literary appreciation learning is often considered to be difficult in practice in the class of language and literature. It is a learning content which will be realized in the behavior of human. This concept needs a wide practice space, with the competence of creative learners and protects learners in the social practice through the learning process.

Literary appreciation is a station for literary learning that can humanize the people in the real life. In practice, the children are guided to understand the process of life, develop positive thinking to the character building and the consciousness to have culture and ecology as the media in life in the cultural local wisdom. Child literary appreciation learning should accommodate the child personality, from the language to the behavior which represents the reality of child life in accordance with the age and characteristics. Whoever writes the children stories or focuses on the ideas of the child's world they should internalize the spirit and characteristics if a child in accordance with the age and environment of their contextual life.

Our local wisdom had been long stated by our pioneers in education and culture. Ki Hajar Dewantara had also given an example how to design a learning curriculum with a proper cultural strategy. The curriculum which is not designed based on our culture will lose the spirit and left an empty space in the heart of our children. Ki Hajar Dewantara made an analogy about education without culture. He said that it is like a ship on the sea without any compass. We do not need to search for the foundation of the curriculum because we have our own rich resources. Soekarno, our founding father, also supported Ki Hajar Dewantara's ideas. Even Soekarno admitted that he did not make Pancasila, but only formulates it from the local wisdom heritage from the ancestors. Therefore, the building character of this nation should be based on our own culture, by exploring the values inherited from the ancestors.

Implementation of child literacy appreciation learning through audiovisual method will stimulate the learners to develop critical learning creativity. The materials of folktales (oral literature) from Kembaran tribe in audiovisual being presented reflects "Digital Ecology Literacy" of local wisdom from Kembaran tribe which has character building elements based on West Papua culture. For the learners, the stimulus which is presented in audiovisual directly will stimulate the ideas about the culture from the learners themselves.

\section{REFERENCES}

Ampera, T. Pengajaran Sastra: Teknik Mengajar Sastra Anak Berbasis Aktivitas. Bandung: Widya.

Aqib \& Murtadlo. (2016). Kumpulan Metode Pembelajaran Kreatif dan Inovatif. Bandung: Yrama Widya.

Chandra, N. E., \& Suyitno, I. (2017). The Representation of Character Education on Teachers Utterances in Early Childhood Learning. ISLLAC : Journal of Intensive Studies on Language, Literature, Art, and Culture, 1(2), 5363.

Huggan, Graham, \& Helen Tiffin. (2010). Poscolonial Ecocritism Literature, Animals, Environment. Canada:Routledge.

Ismawati, E. (2013). Pengajaran Sastra. Yogyakarta: Ombak

Jhin, E. (2014). Contextual Teaching \& Learning (CTL): Menjadikan Kegiatan Belajar-Mengajar Mengasikan dan Bermakna. Bandung: Kaifa

Kurniawan, H. (2009). Sastra Anak dalam kajian Strukturalisme, Sosiologi, Semiotika, hingga Penulisan Kreatif. Yogyakarta: Graha Ilmu.

Lickona, T. (2015). Education for Character: Mendidik untuk Membentuk Karakter. Jakarta: Bumi Aksara.

Rueckert, W. (1996). "Literature and Ecologi: An Experiment in Ecocritism", in Glotfelty and From (1996:105-123).

Samosir, L. A. (2010). Identitas Kembaran dalam Mitos Papua Barat. Adipratama. Jayapura: Papua.

Samosir, L. A. (2015). Dokumenter Audiovisual Identitas Kembaran. Jayapura: Prodivi Papua.

Spradley, J. (2007). Metode Etnografi. Yogyakarta: Tiara Wacana.

Wibowo, A. (2013). Pendidikan Berbasis Sastra. Yogyakarta: Pustaka Pelajar.

Wibowo, A. \& Gunawan. (2013). Pendidikan Berbasis Kearifan Lokal di sekolah. Yogyakarta: Pustaka Pelajar.

Wiyatmi, Else, \& Budiyanto. (2016). Menggagas Pembelajaran Sastra Hijau. Yogyakarta: Interlude.

Wiyatmi, Else, \& Budiyanto. (2016). Pendidikan Lingkungan Melalui Sastra. Yogyakarta: Interlude. 